\title{
proceedings of
}

\section{THE}

\section{7th NEW ZEALAND}

\section{GEOTHERMAL WORKSHOP}

1995

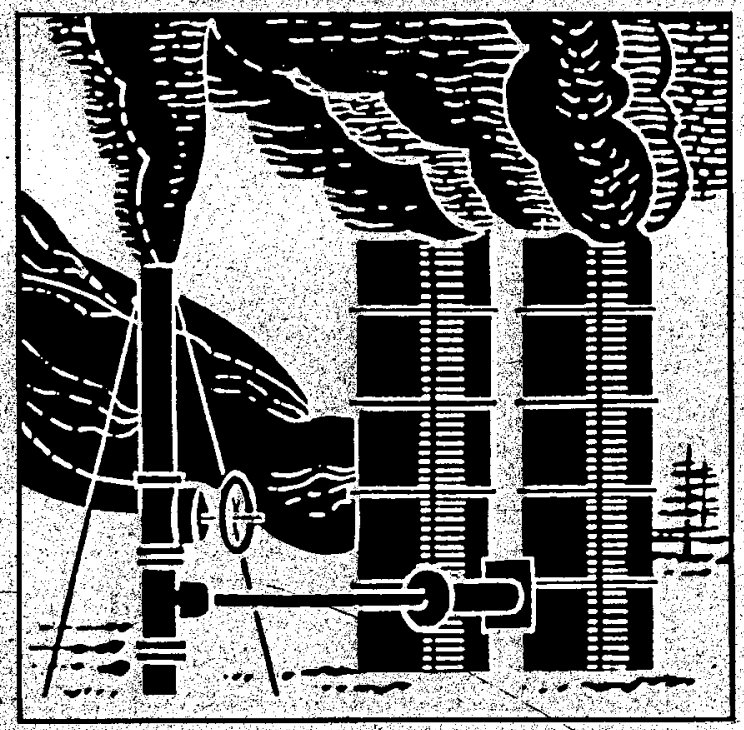

compiled and edited by

M. P. Hochstein, J. Brotheridge and S.F. Simmons

presented by

Geothermal Institute

The University of Auckland

in conjunction with

The Centre for Continuing Education 


\section{DISCLAIMER}

This report was prepared as an account of work sponsored by an agency of the United States Government. Neither the United States Government nor any agency Thereof, nor any of their employees, makes any warranty, express or implied, or assumes any legal liability or responsibility for the accuracy, completeness, or usefulness of any information, apparatus, product, or process disclosed, or represents that its use would not infringe privately owned rights. Reference herein to any specific commercial product, process, or service by trade name, trademark, manufacturer, or otherwise does not necessarily constitute or imply its endorsement, recommendation, or favoring by the United States Government or any agency thereof. The views and opinions of authors expressed herein do not necessarily state or reflect those of the United States Government or any agency thereof. 


\section{DISCLAIMER}

Portions of this document may be illegible in electronic image products. Images are produced from the best available original document. 


\title{
EARTHQUAKE SWARM ACTIVITY BENEATH THE TOKAANU-WAIHI GEOTHERMAL SYSTEM, LAKE TAUPO, NEW ZEALAND
}

\author{
M.P. HOCHSTEIN ${ }^{1}$, S. SHERBURN ${ }^{2}$ AND J. TIKKU ${ }^{1}$
}

${ }^{1}$ Geothermal Institute and Geology Department, University of Auckland, NZ, ${ }^{2}$ IGNS, Wairakei, NZ

SUMMARY: The hypocentres of 4 earthquake swarms (total of 54 events), recorded with a local network between 1986 April and 1987 January, occur within upper crustal rocks of the deeper Tokaanu-Waihi geothermal reservoir; all the events had a magnitude $\mathrm{M}_{\mathrm{L}} \leq 3.2$. Most foci are aligned along two $\mathrm{NW}$-trending basement fault structures along which young rhyodacitic extrusions can be found. The swarm activity has been interpreted in terms of injections into basement fractures of magma from deeper chambers (dyke injection swarm activity).

\section{Introduction}

Earthquake swarms are quite common in the Taupo Volcanic Zone (TVZ) (Smith and Webb, 1986, and Sherburn, 1992a, 1992b). The term 'swarm' is used here to describe a sequence of earthquakes in the upper crust with no recognisable main shock; the epicentres of swarm earthquakes are usually bunched.

Swarm activity in the southern TVZ was recorded with the national seismic network, especially from 1966 onwards when a seismometer near Mt Ruapehu was incorporated in the net. The detectable number of swarms increased significantly when, in 1985, a subnetwork around Lake Taupo was installed - the Taupo Network' referred to by Sherburn (1992b) - which recorded events with a magnitude $\mathrm{M}_{L}>2$. Prior to 1985 , only events with $M_{L} \geq 3$ had been recorded.

Swarm activity is pronounced in the Lake Taupo area (Webb et al., 1986); three of the 11 swarms recorded during the period 1985 to 1987 by the Taupo Network occurred close to Tokaanu (Sherbur, 1992a). One of the three, the 1987 January swarm, has been analysed in detail by Sherburn (1993) who found that the epicentres of the 26 events of this swarm are bunched, and plot within a rather small area of $2 \times 2 \mathrm{~km}$ centred on the village of Tokaanu (Fig. 1); the average focal depth of a few well-located quakes was c. $5 \mathrm{~km}$; the magnitude of the events was in the range $2.0<\mathrm{M}_{\mathrm{L}}<$ 3.2 (Tikku, 1994).

\section{Swarm activity and geothermal activity:}

At present there appears to be a consensus among many NZ earth scientists that earthquake swarms do not occur beneath high temperature geothermal fields. This opinion is probably based on the results of the first micro-earthquake study conducted in the TVZ in 1971/2 (Evison et al., 1976) which showed that the distribution of micro-earthquakes did not correlate with areas of thermal activity. However, even this small survey, lasting only 3.5 weeks, picked up at least one swarm (16 Dec. 71) in the direct vicinity of the Orakeikorako geothermal prospect. Similar studies during the 1970s in Califomia, EI Salvador and Iceland showed that earthquake activity in many high temperature systems occurred primarily as swarm-type sequences (Ward and Björnsson, 1971; Combs and Hadley, 1977). Detailed studies using small local networks were required to record this activity. The magnitude of swarm earthquakes was usually too low to be recorded by regional networks.

Bunching of micro-earthquakes beneath a high temperature geothermal system, however, is anomalous. Micro-earthquake activity of tectonic origin is often significantly reduced beneath and around high temperature systems elsewhere. Such reduction in seismicity was observed for the Coso geothermal system (US), according to a regional seismicity analysis cited in Combs and Rotstein (1976) covering a 20-yr period. For these quakes, which are most likely controlled by a 'stick-slip' mechanism, accumulation of strain appears to be reduced in the anomalously hot crustal rocks beneath a high temperature reservoir. There is therefore the paradox that regional seismic activity in tectonic active areas with geothermal activity is not 'concentrated' near or beneath geothermal prospects but that, with local networks, swarm activity can be found close to or even beneath many of these prospects.

Prior to the establishment of the Taupo Network in 1985, another swarm had been observed beneath Lake Taupo by Webb et al. (1986), namely the 1 July 83 swarm whose epicentres show a clear NW alignment with half of the events lying close to the Horomatangi Reefs. This swarm was not thought to be connected with geothermal activity. However, a recent marine resistivity survey by Caldwell and Bibby (1992) showed that there is a large geothermal reservoir beneath the greater area around the reefs. The northern foci of the July 1983 swarm occurred, therefore, also within a geothermal prospect.

A significant association of earthquake swarms and geothermal activity was indicated when the main swarm events recorded between 1985 and 1987 with the small Taupo Network were summarized by Sherburn (1992a) who found that nearly half of the 11 swarms during this period occurred near geothermal systems. The swarm of 27/28 January 1987 was analysed in more detail (Sherburn, 1993), and the 
epicentres occurred beneath a greater area with thermal manifestations. The inference that this swarm had occurred beneath a high temperature geothermal reservoir was not made since there were few published data available which allowed an assessment of the lateral extent of the reservoir.

Recently we collected the results of all resistivity surveys made in the area. These include data reported by Banwell (1965), an unpublished survey made in 1988 by Geophysics Div., DSIR (report held by ECNZ Wellington), a magnetotelluric survey by Reeves and Ingham (1991), and various smaller studies by Geothermal Diploma students from 1993 to 1995 (summarized in Soengkono and Hochstein, 1995). An integrated plot of these data defines approximately the boundary of the upper $(<0.5 \mathrm{~km}$ depth) reservoir which separates thermally altered reservoir rocks insire $(<30$ ohm $\mathrm{m}$ ) from unaltered rocks outside ( $>100 \mathrm{ohm} \mathrm{m}$ ). This boundary is shown by hatching in Fig. 1. The figures shows clearly that all hypocentres of the 1987 January Tokaanu swarm occurred within the deeper Tokaanu-Waihi geothermal system.

The problem investigated by studies described in this paper was whether other earthquake swarms in the greater Tokaanu area, as recorded during 1986 by the Taupo Network, were also confined to the TokaanuWaihi reservoir, and whether the location of these events was affected significantly by uncertainties in the crustal seismic velocity structure.

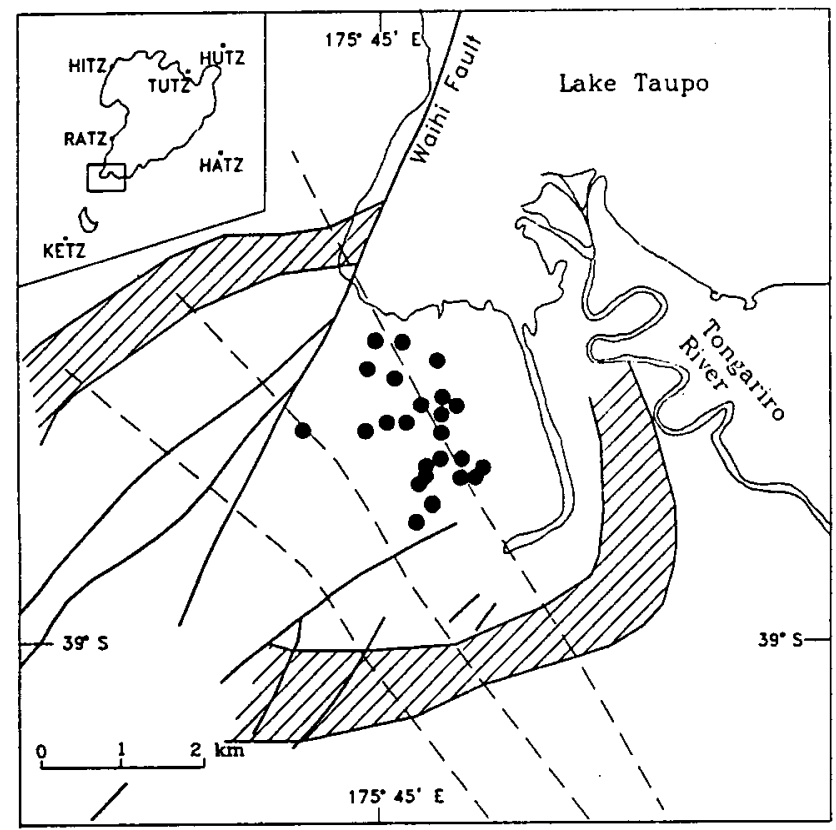

Figure 1: Epicentres of the 1987 January earthquake swarm (taken from Sherbum, 1993). The resistivity boundary enclosing hot, thermally-altered rocks is shown by hatching; active faults of the TVZ fault belt are shown by solid lines; inferred reactivated basement lineaments (from Prebble, 1986) are shown by broken lines.

\section{The Tokaanu-Waihi geothermal prospect:}

Apart from the resistivity structure, widespread thermal manifestations and inactive altered ground also outline the eastern part of the prospect. Active thermal ground is shown in Fig. 2 based on data from Healy (1942), Prebble (1986), Bromley and Mongillo (1991), and Severne and Hochstein (1994). All manifestations lie within the low resistivity area, which covers at least $30 \mathrm{~km}^{2}$. The western extent of the prospect is still unknown; it lies beneath high, rugged terrain.

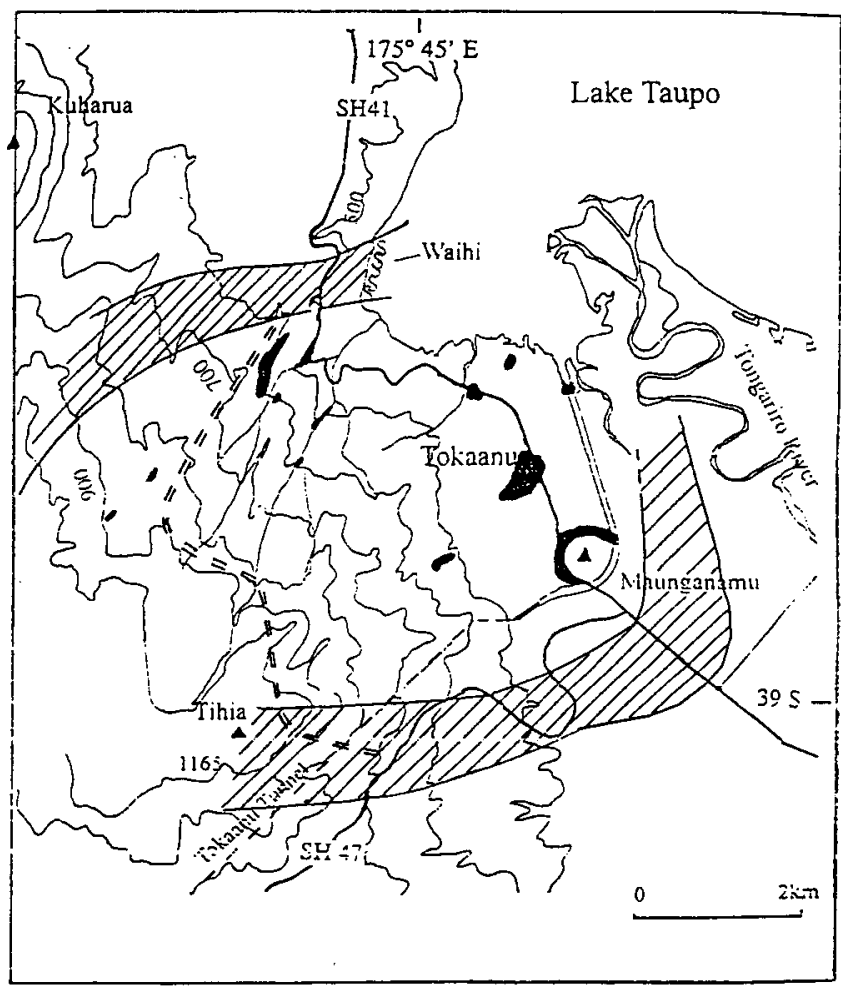

Fig. 2: Topography, thermal ground and manifestations, and resistivity boundary of the Tokaanu-Waihi geothermal system. Thermal manifestations (black patches) are taken from Healy (1942) and Severne and Hochstein (1994); the westem limit of inactive thermally altered ground is shown by a broken double line (from Prebble, 1986).

Geochemical studies by Mahon and Klyen (1968) and Robinson and Sheppard (1986) indicate that the Tokaanu-Waihi system is a liquid-dominated system where hot neutral chloride waters ascend to a level of at least $400 \mathrm{~m}$ in the north-western part of the prospect in the vicinity of the Waihi fault zone (Fig. 1). Shallow boiling probably takes place at temperatures of $c .190^{\circ} \mathrm{C}$ and vapour ascends to the surface along the eroded Waihi fault scarp; the most active transfer of vapour occurs in the Hipaua area (Severne and Hochstein, 1994). After boiling, the hot water moves eastward towards Lake Taupo and is discharged in part by numerous hot pools and springs 
in the Tokaanu Domain and along the lake shore near the village of Waihi.

No deep hole has been drilled yet although a few shallow holes have been drilled to the west of the Domain and along the trace of the Tokaanu tunnel. These holes indicate that the upper reservoir rocks consist predominantly of Quaternary Kakaramea andesites (100 to $200 \mathrm{k} \mathrm{yr}$ ). The volcanic rocks probably extend to at least $1.5 \mathrm{~km}$ depth and are most likely underlain by Jurassic greywacke rocks, here referred to as 'basement' rocks. Ongoing tectonic deformation as a result of the oblique opening of the TVZ has probably reactivated basement faults. Weak, NW-trending lineaments in air photos have been interpreted by Prebble (1986) as activated basement faults (see Fig. 1).

Rhyodacitic intrusions most likely occur in the crust beneath the prospect as indicated by the 'young' dacite dome of Maunganamu which lies close to the Tokaanu power house above low resistivity rocks, and the Kuharua stratovolcano outside the resistivity low (in the upper left corner of Fig. 2) which produced rhyodacitic pyroclastic flows c. $10 \mathrm{k}$ yr ago (NZ Geol. Survey Rec. 22, 1987).

Swarm activity from 1986 April to 1987 January. Tokaanuarea:

Prior to the 1987 January swarm a number of other swarms occurred in the Tokaanu area during 1986. The events were recorded by 3 or 4 stations of the Taupo Network. Characteristics of these swarms are listed in Table 1.

Table 1: Characteristics of swarms (19867). Tokaanu area

\begin{tabular}{l|cccc} 
Date & $\begin{array}{c}\text { Duration } \\
(\mathrm{hr})\end{array}$ & $n$ events & $M_{\max }$ & $D I$ \\
& & & & \\
\hline 86 Apr 20 & 1 & 16 & 3.1 & 0.5 \\
86 Apr 21 & 6.5 & 4 & 2.3 & 0.3 \\
86 July 23 & 1.5 & 3 & 2.6 & 0.1 \\
86 July 28 & 10 & 5 & 2.1 & 0.3 \\
87 Jan 27 & 2 & 22 & 3.0 & 0.1 \\
87 Jan 28 & 1.5 & 4 & 3.2 & 0.2
\end{tabular}

Note: D1 is the difference in magnitude between $\mathbf{M}_{\max }$ and that of the second largest event (Sherburn, 1992).

The two sequences of 20 and 21 April 1986 and 27 and 28 January 1987 probably belong to the same swarm. All the events in Table 1 were analysed recently by Tikku (1994), who initially used a velocity structure based on seismic refraction studies by Stem and Davey (1985) - see Table 2a. In this velocity model, layer 1 represents the infill of Quaternary volcanic rocks, layer 2 the sedimentary basement (greywacke rocks), and layer 3 a deeper crustal layer which probably contains some partial crustal melts (Hochstein et al., 1993).
The velocity model in Table 2 a strictly applies only to the axial region of the TVZ between Taupo and the Bay of Plenty. To the south of Taupo the seismic velocity of the upper crust appears to increase slightly (Stern and Davey, 1985). The velocity structure between Taupo and Mt Ruapehu, however, is still poorly known. For the analysis of the events in Table 1, Tikku (1994) assumed three scenarios:

1. The crustal seismic velocity structure between $\mathrm{Mt}$ Ruapehu (KETZ station in inset of Fig. 1) and Taupo (TUTZ) is the same as that in Table $2 a$.

2. The crustal velocities in the upper $5 \mathrm{~km}$ are c. $10 \%$ greater (HI model in Table 2b) than those in scenario 1.

3. The velocities in the upper $5 \mathrm{~km}$ are c. $10 \%$ less than those in scenario 1 (LO model in Table $2 b$ ).

The justification for the LO model is given by the observation that seismic velocities in the upper crust beneath the geothermal system of Broadlands-Ohaaki are about 10\% lower (Henrys and Hochstein, 1990) than those of the TVZ crustal model. Any seismic ray emerging from the deeper Tokaanu system would have to pass through the Tongariro thermal system when recorded at KETZ station; likewise, any ray travelling to the NW could be affected by the Lake Taupo thermal systems (Caldwell and Bibby, 1992).

Table 2a: Crustal velocity structure of TVZ (Scenario 1)

\begin{tabular}{l|ccc} 
Layer & $\begin{array}{c}\text { Depth } \\
\text { range }(\mathrm{km})\end{array}$ & $V_{p}(\mathrm{~km} / \mathrm{s})$ & $v_{s}(\mathrm{~km} / \mathrm{s})$ \\
\hline & & & \\
1 & $0-2$ & 3.2 & 1.85 \\
2 & $2-5$ & 5.5 & 3.2 \\
3 & $5-15$ & 6.15 & 3.55 \\
4 & $>15$ & 7.4 & 4.3 \\
\hline
\end{tabular}

Table 2b: HI and LO crustal velocity structure of TVZ

\begin{tabular}{l|cccccc} 
Layer & $\begin{array}{c}\text { Depth } \\
\text { range }(\mathrm{km})\end{array}$ & \multicolumn{2}{c}{$V_{p}(\mathrm{~km} / \mathrm{s})$} & \multicolumn{2}{c}{$v_{s}(\mathrm{~km} / \mathrm{s})$} \\
& & HI & LO & $H I$ & $L O$ \\
\hline 1 & $0-2$ & 3.52 & 2.7 & 2.0 & 1.5 \\
2 & $2-5$ & 6.0 & 5.0 & 3.52 & 2.7 \\
3 & $5-15$ & 6.35 & 6.0 & 3.65 & 3.5 \\
\hline
\end{tabular}

Only 8 of the 54 events listed in Table 1 were associated with clear $p$ and $s$ arrivals recorded at 3 stations which allowed an estimate of the focal depth (mean: $5 \pm 3 \mathrm{~km}$ ). All other events were analysed by restricting the focal depth to $5 \mathrm{~km}$. The epicentres were computed using the iterative Geiger method. 


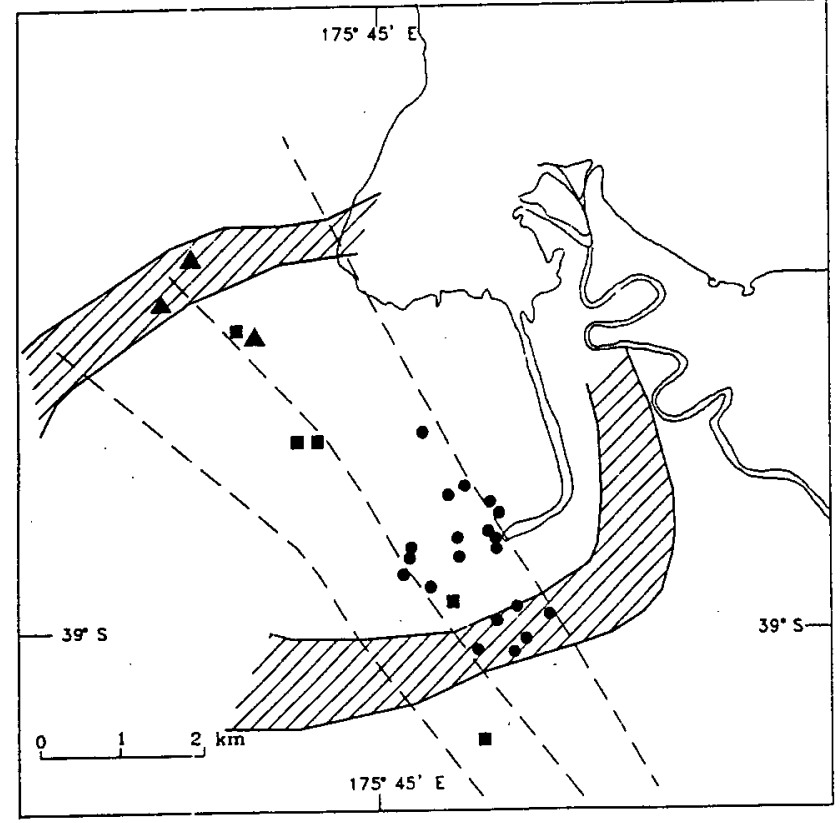

Fig. 3a: Epicentres of three earthquake swarms computed with the TVZ velocity model.

Solid dots: $20-21.4 .86$ swarm, solid triangles: 23.7 .86 swarm, solid squares: 18.12 .86 swarm.

Since most events were only recorded by 3 stations (HATZ, KETZ and RATZ - see inset of Fig. 1), and because the Tokaanu area lies close to the centre of this array, it was unlikely that the epicentres were much affected by the choice of the velocity model. However, the time residuals (observed minus theoretical travel time) would be affected. Hence, this parameter was analysed to test the hypothesis whether mean and standard deviation of residuals differed significantly for the three velocity models. The uncertainties in epicentre position were also analysed using significance tests.

\section{Results:}

The epicentres of the swarms between 20 April and 28 December 1986 are shown in Figs. 3a and 3b; those in Fig. 3a were computed with the TVZ seismic velocity model (Table $2 a$ ), those in Fig. $3 b$ with the HI model (Table 2b). Epicentres obtained with the LO model are not presented but show a pattern similar to that in Figs. 3a and 3b.

All epicentres in Figs. $3 \mathrm{a}$ and $3 \mathrm{~b}$ are located inside the low resistivity structure which outlines hot and thermally altered rocks in the upper $0.5 \mathrm{~km}$ of the Tokaanu-Waihi reservoir, except for one event of the 1986 December swarm which lies outside the boundary in the south. The 3 events of the small 1986 July swarm occurred close to the thermally

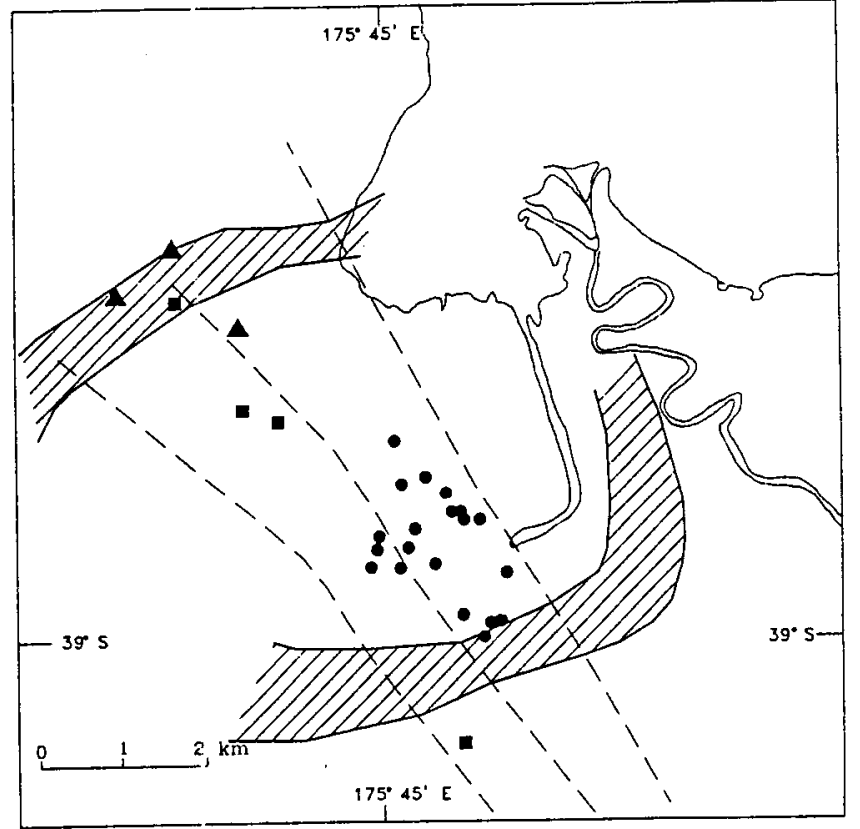

Figure 3b: Epicentres of three earthquake swarms computed with the HI velocity model; for details see caption to Fig. 3a.

active Hipaua area (Fig. 2). The epicentres of the 1986 July and 1986 December swarms are aligned and lie close to an inferred NW-trending basement fault as mapped by Prebble (1986) which passes through the young stratovolcano of Kuharua. Since all events except one shown in Fig. 1 and Fig. 3a lie inside the low resistivity structure, significance tests can be applied to all 54 events. The mean time residuals of these events were found to be:

HI model: $0.148 \pm 0.024 \mathrm{sec}$;

TVZ model: $0.154 \pm 0.024 \mathrm{sec}$;

LO model: $0.244 \pm 0.026 \mathrm{sec}$.

Using a STUDENT t-test, it was found that the solutions obtained with the LO model are significantly different (at $\mathrm{p}=0.95$ ) from those given by the $\mathrm{HI}$ and TVZ velocity models. Since the mean residual of the LO model data is also significantly greater, the LO velocity model is a poor fit of the actual crustal velocity structure. Although the mean residual of the HI model is slightly less than that derived from the TVZ model, there is no significant difference between the two means even at $p=0.99$. It is, however, possible that the best fit velocity structure lies between the two models, i.e. between the TVZ and the HI model. The relative uncertainty in the position of the events plotted is for both models $\mathrm{c}$. $\pm 450 \mathrm{~m}$ with a maximum in NW direction (at $p=0.95$ ); this result is similar to that of an earlier analysis (Sherburn, 1993). The sequence of events in each of the larger 
swarms exhibits no significant pattern; the first quake occurs near the centre of the cluster; the position of later swarm events occur randomly with respect to the centre.

\section{Discussion of events}

Analysis of 4 earthquake swarms that occurred in the Tokaanu area between 20.4.86 and 28.1.87 has shown that the hypocentres occur within the greywacke basement of the deeper Tokaanu-Waihi geothermal reservoir. Most of the 28 events shown in Fig. 3a are aligned along $\mathrm{NW}$-trending basement lineaments along which young extrusions are located. Given the relative uncertainty in epicentre position it is possible that nearly half of the foci in Fig. 1 are also aligned.

Alignment of epicentres of swarm events beneath geothermal reservoirs is not a new finding. It was mentioned earlier that the foci of the swarm beneath the Horomatangi Reefs geothermal prospect also show an alignment whose direction is almost perpendicular to that of the active faults of the Taupo Volcanic fault belt. Many swarms associated with high temperature systems in the Reykjanes area (Iceland) and in the Imperial Valley (US) show similar alignments (cited in Hill, 1987), although other swarms in the same area often show a cluster of epicentres. Swarm activity beneath high temperature geothermal systems can therefore produce both clustered and aligned epicentres. If 'stick-slip' mechanism were reduced in the anomalously hot rocks beneath high temperature reservoirs, as indicated by the analysis of regional seismicity in the greater Coso area (US) mentioned previously, it is likely that other mechanisms produce the swarm activity beneath or near geothermal systems.

A model that explains such activity in volcanic regions has been proposed by Hill (1977). According to Hill, magma injection into dykes within the brittle crust can lead to a sequence of shear failure along a system of conjugate faults. There is indeed one example where aligned swarm activity beneath high temperature reservoirs was followed later by dyke extrusions at the surface, namely in the KraflaNamafjall area in Iceland. Here, Ward and Björnsson (1971) observed in the summer of 1968 a swarm with well aligned (NNE-trending) foci beneath the thermal areas; from 1976 onwards a sequence of aligned basaltic extrusions occurred at Krafla.

Since some 'young' ( $<10 \mathrm{k}$ yr) extrusions have occurred in the direct vicinity of the Tokaanu-Waihi prospect whose feeder channels were probably controlled by the same basement lineaments along which swarms occurred in 1986/7 (see Figs. 1 and 3a), we propose a model where swarm activity beneath the Tokaanu-Waihi prospect is caused by magma injection into basement dykes. Although the radio-metric age of the nearby 'young' extrusions is poorly known, it is unlikely that a parent magma body which fed these extrusions would have solidified by conductive heat transfer within a period of $<10 \mathrm{k}$ yr if volumes of $>1$ $\mathbf{k m}^{3}$ were involved.
The model of dyke injection as source mechanism for the Tokaanu-Waihi earthquake swarms can be tested by first motion analysis of records from a densely-spaced seismic network. The Taupo Network (1985-1991) was too widely spaced, thereby preventing such analysis. Another test would be provided by monitoring non-reactive volcanic gases discharged by fumaroles in the Hipaua area.

\section{Acknowledgment}

The authors acknowledge the assistance of $\mathrm{Mr} \mathrm{N}$. Kortwright (ECNZ, Wellington) who released resistivity data (1988 survey by Geophysics Div., DSIR) for this study which were used for the construction of the resistivity boundary shown in Fig. 2.

\section{References}

Banwell, C.J. (1965). Tokaanu/Geophysics. In: Thompson, B.N., Kermode, L.D., Ewart, A. (Eds.): New Zealand Volcanology - Central Region. DSIR Information Series 50: 152 155.

Bromley, C., Mongillo, M. (1991). Infra-red video survey of Tokaanu-Waihi Geothermal Field. Proc. 13th NZ Geothermal Workshop, The University of Auckland, 27-32.

Caldwell, T.G., Bibby, H.M. (1992). Geothermal implications of resistivity mapping in Lake Taupo. Proc. 14th NZ Geothermal Workshop, 207-212.

Combs, J., Rotstein, Y. (1976). Microearthquake studies at the Coso geothermal area, China Lake, California. Proc. 2nd UN Symposium on Development and Use of Geothermal Resources, vol. 2, 909-916.

Combs., J., Hadley, D. (1977). Microearthquake investigation of the Mesa geothermal anomaly, Imperial Valley, California. Geophysics 42: 17-23.

Evison, F.F., Robinson, R., Arabasz, W.J. (1976). Microearthquakes, geothermal activity, and structure, Central North Island, New Zealand. NZ Journ. Geol. Geophysics 19: 625-637.

Healy, J. (1942). Boron in hot springs at Tokaanu, Lake Taupo. NZ J. Science and Technology 24: 1-13.

Henrys, S.A., Hochstein, M.P. (1990). Geophysical structure of the Broadlands-Ohaaki geothermal field (New Zealand). Geothermics 19: 129 150.

Hill, D.P. (1977). A model for earthquake swarms. Journ. Geophys. Res. 82: 1347-1352. 
Hochstein, M.P., Smith, I.E.M., Regenauer-Lieb, K., Ehara, S. (1993). Geochemistry and heat transfer processes in Quaternary rhyolitic systems of the Taupo Volcanic Zone, New Zealand. Tectonophysics 223: 213-235.

Mahon, W.A.J., Klyen, L.E. (1968). Chemistry of the Tokaanu-Waihi hydrothermal area. NZ J. Science 11: 140-158.

Prebble, W.M. (1986). Geotechnical problems in the Taupo Volcanic Zone. In: Gregory, J.G., Watters, W.A. (Eds): Volcanic hazard assessment in New Zealand. NZ Geological Survey Record 10: 65-80.

Reeves, R., Ingham, M. (1991). Electrical structure of the Tokaanu geothermal field. Proc. 13th NZ Geothermal Workshop, 21-25.

Robinson, B.W., Sheppard, D.S. (1986). A chemical and isotopic study of the Tokaanu-Waihi geothermal area, New Zealand. J. Volc. Geotherm. Research 27: 135-151.

Severne, C.M., Hochstein, M.P. (1994). Heat and mass transfer of the Hipaua thermal area (Tokaanu-Waihi geothermal field), Lake Taupo, New Zealand. Proc. 16th NZ Geothermal Workshop, The University of Auckland, 209214.

Sherburn, S. (1992a). Characteristics of earthquake sequences in the Central Volcanic Region, New Zealand. NZ Journ. Geol. Geophysics 35: 57-68.

Sherburn, S. (1992b). Seismicity of the Lake Taupo region, 1985-90, New Zealand. NZ Journ. Geol. Geophysics 35: 331-335.
Sherburn, S. (1993). The 1987 January Tokaanu earthquake sequence, New Zealand. NZ Journ. Geol. and Geophysics 36: 61-68.

Smith, E.G.C., Webb, T.H. (1986). The seismicity and related deformation of the Central Volcanic Region, North Island, New Zealand. In: I.M. Smith (Ed.): Late Cenozoic volcanism in New Zealand. Royal Soc. New Zealand Bull. 23: 112-133.

Soengkono, S., Hochstein, M.P. (1995). Application of magnetic method to assess the extent of high temperature reservoirs. Proc. 20th Annual Workshop 1995, Geothermal Reservoir Engineering, Stanford University, 71-78.

Stern, T.A., Davey, F.J. (1985). Crustal structure studies within the central North Island: the Central Volcanic Region. Geophys. Div. Report 207, Dept. of Scientific and Industrial Research, Wellington.

Tikku, J. (1994). 1986-87 Microearthquake swarm analysis (Tokaanu-Waihi geothermal area, Taupo Volcanic Zone, New Zealand). Unpubl. Project Report 94.25, Geothermal Institute, lodged with the Library, University of Auckland.

Webb, T.H., Ferris, B.G., Harris, J.S. (1986), The Lake Taupo, New Zealand, earthquake swarms of 1983. NZ Journal Geol. Geophysics 29: 377-389.

Ward, P.L., Björnsson, S. (1971). Micro-earthquakes, swarms, and the geothermal areas of Iceland. Journ. Geophys. Res. 76: 3953-3982. 